\title{
SHAPING DESTINATION MARKETING THROUGH TRAVEL BLOGS: UNDERSTANDING EGYPT'S ATTRIBUTES AFFECTING BLOGGERS' CHOICE
}

\author{
Lamiaa Hefny \\ Assistant Professor, Department of Tourism Studies \\ Faculty of Tourism and Hotels Management, Pharos University
}

\begin{abstract}
Travel blogs are considered an important tool for destination marketing. Bloggers' narrative reflects their tourist experience and their comments often contain recommendations and their intentions to revisit the destinations their stories are about. Travel blog monitoring is considered an effective method for destination marketers to assess their service quality and improve travelers' overall experiences. The purpose of this study is to examine how travel blogs can be a powerful tool through the e-WOM in destination marketing. The study used a qualitative research to analyze blogs content and demonstrate Egypt's attributes that made bloggers' choice. Tourism destination marketing organizations in Egypt could develop successfully their attractions and service quality through generated travel blogs information.
\end{abstract}

Keywords: e-WOM, Travel blogs, Destination Marketing.

\section{Introduction}

By the beginning of the 2000s, destination marketing organizations have been challenged by the rise of the internet but at the same time enormous opportunities have opened up. The internet had become a creative opportunity for communications, distribution channels, transactions and share content despite the socio-cultural differences and geographical distances.

Word of mouth from consumers is a powerful tool and one of the goals in the marketing and substantial in tourism industry. The evolution of technology has turned on the traditional word of mouth has into a 'virtual word of mouth'. Marketers and tourism destinations have to understand and cope with the threats of credibility, relevance and trustworthiness of such form of electronic word of mouth (e-WOM), while at the same time trying to harvest the potential data and information that word of mouse has created (Volo,2010).

Shared words and photographs on social media are considered as reliable form of (e-WOM). These words and photographs are the reflections of tourists' real evaluations, opinions and experience in the destination ( $\mathrm{Li}, 2015)$. The shared content could be an information source for tourists and necessary for destination tourism marketers to use it in several different management and marketing areas.

A form of communication by word of mouth developing communication technologies are blogs. Blogs have recently become an influential medium and have demonstrated enormous marketing power. Consumers can freely conduct ongoing information searches through this new channel. 
However, the credibility of blogs plays an important role in creating opportunities for positive customer experiences that can shape consumers' product/service purchase intentions and decisions (Hsu and Tsou, 2011: p.510). In Travel blog, tourists often publish their own personal travel stories and advice in the form of logs or product reviews. (Schmallegg's and Carson, 2008: p.99-110). Therefore, revealing all aspects of a tourist's experience in a travel blog can be used as a communication tool to understand the tourist's perception. Blogs are considered one of the types of (eWOM) poses new possibilities and challenges for tourism marketers (Dellarocas, 2003).

The purpose of this study is trying to demonstrate the travel blogs' experiences in Egypt, define its' strengths and weaknesses as a tourism destination from bloggers' views and finally how tourism marketers could use these travel experiences to improve Egypt's tourism products and services.

\section{Literature review}

\section{Destination choice and tourism destination marketing}

It is important to better understand the main drivers affecting the choice and later evaluation of a tourism destination experiences. Destination choice is a complex process and the studies of destination choice have focused on the impacts of the attributes such as basic tourist personality traits (Lepp and Gibsonb, 2008), distance to or prices of a destination and climate information in a destination (Nicolau and Más, 2006). Tourism destination marketing can assess the suitable facilities and activities for visitors. A key factor to success for destination marketing organizations is the integration of information technologies (Wang, 2012). Due to the developments in search engines, carrying capacity and speed of network, the number of individuals, using technologies for planning and experiencing their travels is increasing (Buhalis and Law, 2008). For tourism organizations, both private and public, the internet has become one of the most important marketing communication channels (Wang and Fesenmaier, 2006).

\section{WOM and e-WOM}

Word of Mouth (WOM) can be defined as "communication about products/services between people, who are perceived to be independent of the company providing it" (Silverman, 2001:p.27). Jalilvand, Esfahani, and Samiei, (2011:p.43) define the phrase word of mouth as "a process for consumers to share information and opinions about a product or service to others". Word of Mouth is essential because it provides companies with the real perceptions and attitudes of current customers and future ones (Silverman, 2001). WOM is always conducted between two parties: the source of the information and the receiver (López, and Sicilia, 2014). The main characteristic of WOM is that the source is independent, has no commercial interest in providing WOM, and that kind of communication process is more credible than firm-generated information (López, and Sicilia, 2014). This is very essential in the tourism industry since the product is being bought prior to consumption and experiences are intangible ( $\mathrm{Gu}$ et al. 2009). Sharing consumers' attitudes and behaviors on the Internet is often called electronic Word of Mouth (e-WOM).

The difference between traditional Word of Mouth and e-Word of Mouth is that in e-Word of Mouth, recommendations are usually from unknown individuals. This consequently makes it difficult for consumers to determine the credibility of online reviews (Bonner and De Hoog, 2011). E-WOM is defined as "any positive or negative statement made by potential, actual or former customers about a product or company, which is made available to a multitude of people and institutions via the 
Internet" (Hennig-Thurau, et al, 2004, p. 39). Although WOM and e-WOM both provide consumers' opinions about a product or brand, they do not use the same channels to transmit information, and therefore are dissimilar. As Figure 1 shows, WOM occurs in a simultaneous and bidirectional conversation, face to face between source and receiver (Hansen and Lee, 2013). However, in e-WOM the conversation does not have to be simultaneous and bidirectional. The source writes an opinion on the Internet that can stay there for a long time. Thus, many consumers can see this opinion and decide whether to answer the source. The permanence of the opinion increases the level of information exchange compared to traditional WOM communication (Hennig-Thurau, et al, 2009).

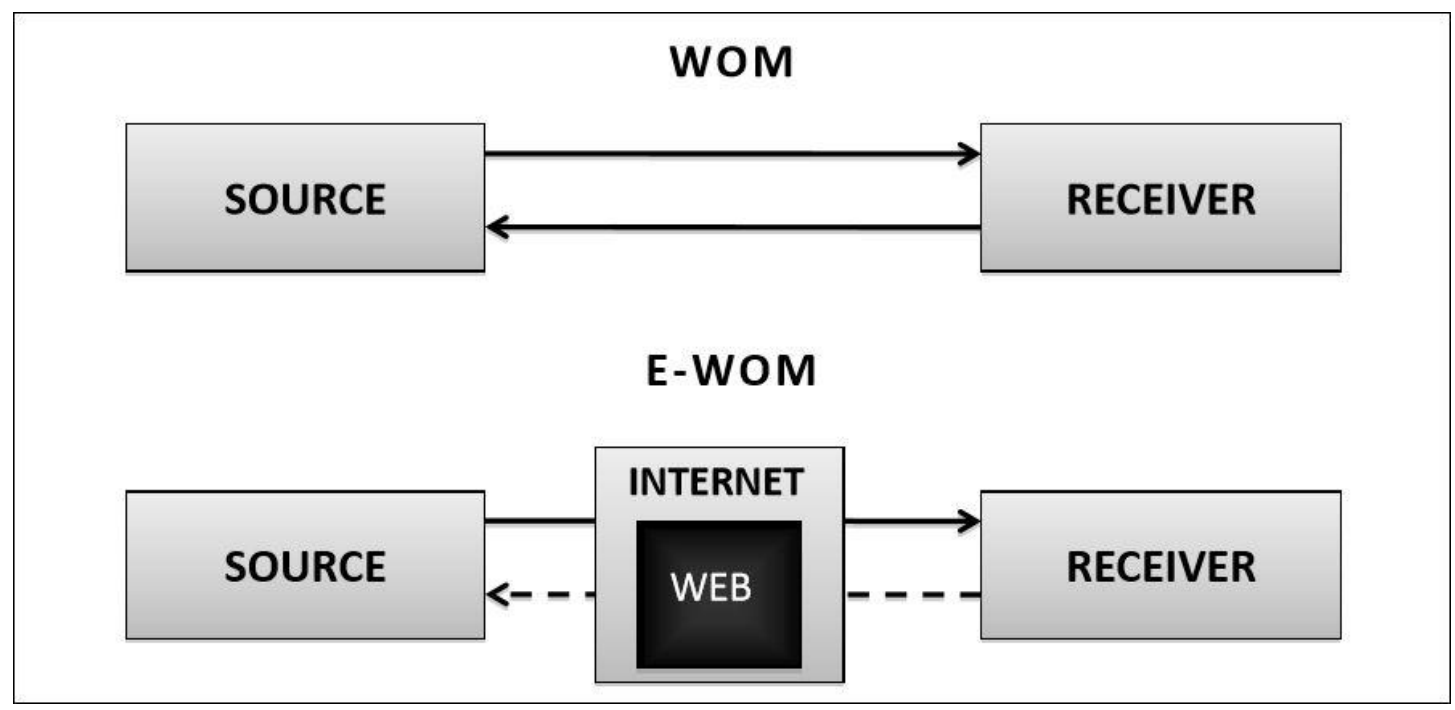

Figure 1: WOM vs. e-WOM. Source: Adapted from (López and Sicilia, 2014)

Cheung, and Lee (2012), claimed that there were different patterns in the way people might present and exchange their opinions through e-WOM. Consumers might simply write down their opinions, suggestions or comments on products or services. E-WOM channels can be summarized as follows: One-to one channel refers to messages that are sent from one person to another. This can be seen when one person sends an email or instant message to another. One-to-many channel refers to messages that are sent from one person to other people. This can be done when one person makes a comment about products or services on online chat rooms, websites, or product review websites. Many-to-many channel refers to messages that are sent from many people to other people. This can be done when many people post their messages on blogs, Virtual communities, online communities, Newsgroups such as in Google group, or Yahoo group. Blogs, virtual communities, newsgroups, review sites and chat rooms are communication channels and each has its own level of interactivity as shows in figure 2. Readers access these sources at different times (Goldsmith, et al, 2008).

E-Word of Mouth marketing provides an opportunity to compare information regarding e-consumers' experiences (Mills, Law 2004). E-WOM has become an increasingly popular way of obtaining competitive advantage. E-WOM is especially relevant with regard to tourism, specifically tourists' attitudes toward destinations (Albarq, 2014). 


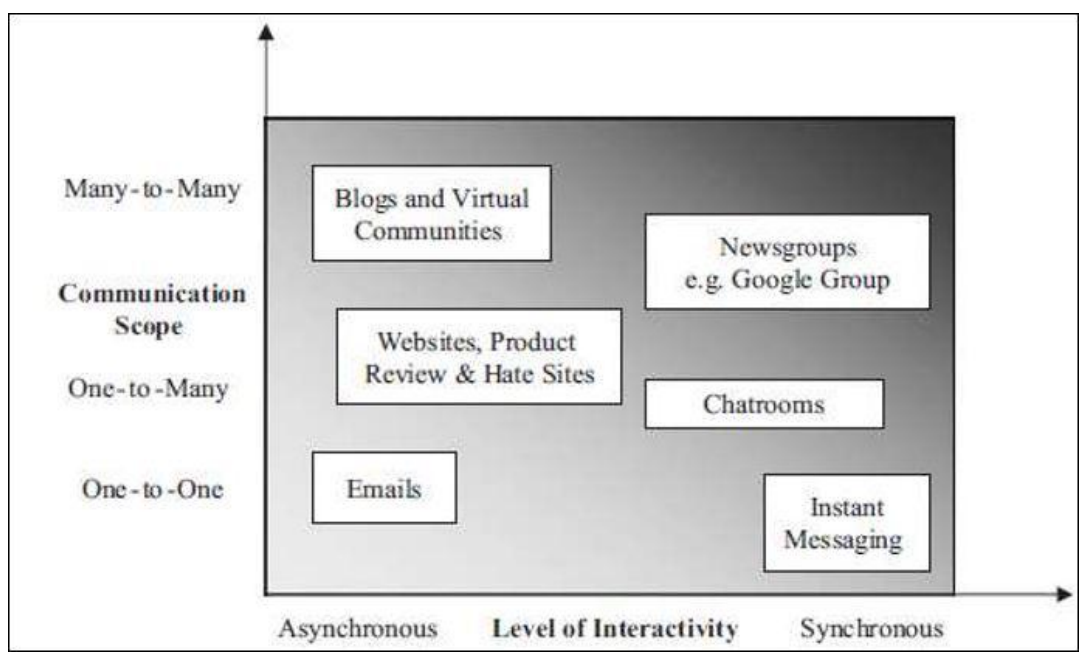

Figure 2 - Typologies of e-Word of Mouth (Goldsmith, Litvina and Pana, 2008)

\section{Travel blogs and bloggers}

Blogs, short for (weblogs), are free public web based journals. Sharda and Ponnada, (2008: p.159) defined blogs as "virtual diaries created by individuals and stored on the web for anyone to access". This digital form of journaling gathers people's experiences, creating a word of mouse characterized by: ease of access, written format and anonymity (Dellarocas, 2003). There are six important components separating blogs from other means of communication (Arat, 2016):

1) Publishable: It can be done in a very cheap way and it becomes instantly available worldwide. 2) Findable: People access issues, author or both of them by the help of search engines. 3) Social: The blogosphere (blogs environment), It is a great conversation area. People through blogs, "with shared interests" of the relationship restricted geographically. 4) Viral: Information, through blogs is spreading faster than spread through news services. The speed and effectiveness of a blog is too fast to match any verbal form of marketing. 5) Syndicatable: Blogs, by clicking the RSS icon, it will be easier to pick the address of RSS applications. 6) Linkable: Because each blog can link to others, every blogger can reach millions of people every day. According to figure 3 the total blogs from May 2011 to April 2016 had surpassed 291.7 million blog accounts, up from 227.1 million in the previous year (Statista, 2016).

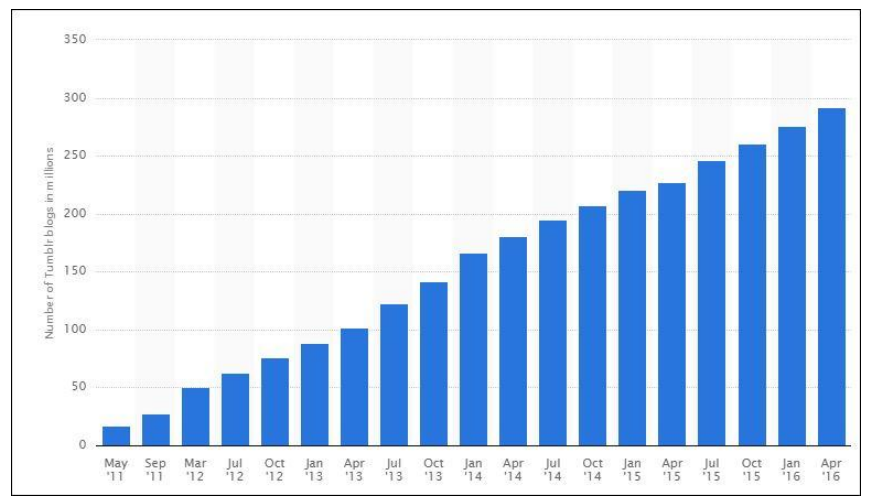

Figure 3: Total number of blogs. Source: Statista 2016 
Since blogs are an informal communication channel consumers can associate with the recommendations made by bloggers and the readers feel more positive about their non-commercial opinions (Hsu et al., 2013). It is considered that e-WOM through personal blogs about a product or service is more influential than the information of the marketers (Lee and Youn, 2009). Schmallegger and Carson, (2008) noted that travel blogs originated from the concept of virtual traditional travel communities and had the characteristics of information sharing, social interaction, and high credibility. Travel blogs combine texts, images, videos, audios, links and a collection of tools to share authors' commentaries or news while they are travelling (Volo,2010). Given the intangible nature of travel products, the information and recommendations provided by blogs are richer and more reliable than those who offered traditionally. Travel blogs are hosted on provider sites, a growing number of which are tourism specific such as virtualtourist.com and tripadvisor.com. Increasingly, guidebooks are referring people to such sites or hosting their own blog forums (Pühringer and Taylor, 2008).

\section{Travel blogs vs. traditional destination marketing messages}

Pan et al. (2007) conclude that the motivations for blogging are documenting one's life, as a social commentary and outlet for their feelings. That is indicating that individuals that blog are honest and realistic about their travel experiences and that travel blogs are genuine. Because travel agencies tend to show only the positive aspects of the travel location, readers may favor the factual information about the location that is presented on blogs (Pudliner, 2007; Sharda \& Ponnada, 2008). Although blogs may provide authentic information which is not always positive, the information contains honest observations and opinions. Bickart and Schindler, (2001) discussed that one of the main characteristics of travel blogs that their greater influence on the decision-making process of consumers than traditional marketing messages. An important aspect of travel blogs is the presence of personal experiences, which cannot be found when looking at online marketing destination information (Dalen, 2014). Additionally, the written personal experiences by the author are more authentic than when written in by a traditional marketer. Because the blogger has actually experienced the journey, the provided information will reflect the performance of typical tourism products.

This is not the case when a traditional marketer writes about a particular tourism product, because the marketer might never actually experience the journey before (Dalen, 2014). Bickart and Schindler (2001) notice that studies only focused on the textual content of travel blogs, However, pictures of destinations are often included and can have an influence on the destination image formation and decision making process as well. Tourism bloggers are driven by their desire to share their experience with their family and friends, as well as other prospective tourists. Despite the fact that bloggers are "self-designated authorities (Gelb and Sundaram, 2002, P.22) and that they cannot be assumed to be representative of the general population of consumers or travellers, they are never less important and somewhat the authoritative voice on the marketplace (Volo, 2010). Thus, these are the factors that are considered to determine the power of a blogger's e-WOM.

\section{How can Destination management organizations (DMOs) use travel blogs?}

Travel blogs do include a range of information which may be very useful for Destination management organizations (DMOs). This includes comparisons and contrasts between individual and groups of destinations, critiquing of activities or attractions at destinations, reviews of accommodation establishments and so on. They often contain images and their writers can dynamically link readers to supplier websites and other related sites. Blogs tend to be interactive and readers post comments (Pan 
et al. 2007; Kelleher and Miller 2006; Ellion, 2007). The activities of blogs and bloggers have become known as the "blogosphere" (Carson 2008). Specific tourism sites such as tripadvisor.com and travelpod.com enable consumers to exchange information, opinions and recommendations about destinations, tourism products and services, with sometimes diaries of travel experiences and ratings of a particular product or hotel. Next to these sites, there are the public travel blog sites specializing in hosting individual travel blogs include travelblog.org, travelpod.com, travelpost.com and yourtraveljournal.com. In addition, well-known travel guides provide web space to publish travel stories, for example, lonelyplanet.com and community.roughguides.com (Carson 2008). Blogs are not just growing in consumer to consumer $(\mathrm{C} 2 \mathrm{C})$ communications; it includes business to business (B2B), business to consumers (B2C), government to businesses (G2B) and government to consumers $(\mathrm{G} 2 \mathrm{C})$ (Monga, et al 2015).

G2C blogs often hire experienced and professional bloggers as "opinion leaders" (Price and Starkov, 2006), while recently, destination blogs have engaged local people to provide information and in so doing make the information more trustworthy. Some state and regional tourism organizations in the USA are using paid or sponsored bloggers and some European destinations such as Amsterdam are also using this approach. Tourism enterprises have also realized that blogging may be cheaper and possibly more effective than advertising (Waldhor 2007; Pan et al. 2007; Choi et al. 2007).

Blogs have a value for marketing, management and marketing research. Clearly intensive use of blogs can be used for customer profiling, customer acquisition, customer engagement, brand awareness, brand reinforcement, reputation management, customer service, analyzing competitor strategies and market research (Litvin et al. 2007). Careful analysis of blogs enables tourism organizations and enterprises to assess market segments or uncover unsuspected strengths and weaknesses of a destination or tourist organization (Choi et al. 2007). The usefulness of Travel blogs for providing DMOs with insights into the types of word of mouth messages being transmitted about the destination is evident. It is very important for destinations to understand and monitor this aspect of Travel blogs in formally research ways in which Travel blogs can be incorporated into its online and marketing strategies (Pühringer and Taylor, 2008).

\section{Current travel blogs researches}

An examination of travel blog research conducted revealed that a majority of researchers utilized content analysis and narrative analysis to analyze travel blogs (Banyai and Glover, 2012). Content analysis was employed in the majority of studies examining travel blogs. In these cases, attention was given to activities undertaken at the destination strengths/weaknesses, Positive/negative perceptions, Descriptions of lived experiences, Common topic themes, attractions, accommodation, transportation food and beverage (Carson, 2008; Wenger, 2008; Pan et al, 2007). Wenger (2008), for example, analyzed 114 travel blogs related to trips to Austria to understand similarities and differences between the blog posts and Austria's tourism markets, and to identify positive and negative perceptions of Austria as a tourism destination. Similarly, Carson (2008) content-analyzed 25 blogs about travel to Australia's Northern Territory with attention being given to comments related to locations, activities, tourism products, events, and transportation. Content analysis was also used to monitor visitor attitudes in terms of positive, negative, and neutral experiences. Pan, et al (2007) content analyzed 40 blogs related to travel to Charleston, South Carolina, to gain an understanding of travelers' experiences, and of Charleston's strengths and weaknesses as perceived by tourists. By content 
analyzing travel blogs, researchers can gain access to “every aspect of a visitor's trip (Banyai and Glover, 2012).

Content analysis can also be utilized to discover gaps in tourism promotion. When content analyzing Macau related Internet sites, Choi, et al (2007) found that tourists' impression of Macau is that of a historical heritage city, but that the images portrayed by tourists did not match those promoted by the official tourism office. Banyai, (2010) also found that tourists' image of Dracula as a tourism attraction does not correspond with that promoted by Dracula Castle tour guides. By identifying these gaps destination marketers can address and improve their marketing strategies by promoting a destination image based on the tourists' impressions, perceptions, demands and expectations of the tourism product. While content analysis is the most popular methodology used to analyze the content of travel blogs, narrative analysis is gaining ground.

Narrative analysis as a research methodology has been used to gain insights into Descriptions of lived experiences, Temporal, spatial dimension and Identity creation (Tussyadiah \& Fesenmaier, 2008; Berger \& Greenspan, 2008). Tussyadiah and Fesenmaier (2008) used narrative structure analysis to identify key marketing elements from tourists' blogs to aid DMOs in facilitating and managing travel blogs. The data sample was selected from tourists' blogs posted on the Pennsylvania Tourists Office website. The narrative structure analysis of the Pennsylvania blogs included characterization, temporal dimension, relational organization, and space categorization. Berger and Greenspan (2008) used narrative analysis to examine the involvement of technologized storytelling in the creation and manifestation of identities. The blog diary of the 2005 Canadian Everest Expedition provided the researchers with a portrait of climbers' struggles, adaptations, celebrations, grief, and relationships between travelers, the mountain, and supporters around the world. Narrative analysis on travel blogs offers researchers and destination marketers' insight into how tourists create meanings and identities based on their travel experiences. By using narrative analysis on travel blogs, tourism researchers were able to note the underlying patterns across various travel experiences by uncovering the common plots in the travel blogs (Banyai and Glover, 2012).

\section{Methodology}

This study aims to analyze travel blogs to identify the different points of view of visitors that describe their travel experiences in Egypt as key features for the destination management organizations (DMOs) to benefit from. The study describes how bloggers as tourists see Egypt and its tourism facilities. Three main steps were followed to conduct this research. The first step is about searching individual and specialized travel blogs that will constitute the database of our study. The second step consists of analyzing these blogs, and extracting only the relevant ones by eliminating those that do not meet certain criteria that will be discussed later. The third and final step is extracting information from each blog entry. The main purpose of our work is to answer three main questions:

What are the negative and positive evaluations of Egypt as a tourist destination from bloggers point of view?

Why bloggers choose Egypt as a holiday destination and what are the main reasons for that?

What are the recommendations that can be given from the research findings to tourism marketers in Egypt to improve our tourism service? 


\section{Sampling and data collection}

The described research is considered an exploratory study. The data for this research was gathered from travel blogs texts (secondary data), which led to choose a qualitative research method. Content analysis as analytical tool was found to be the most suitable technique to perform massive analyses of blogs and reviews (Mariné-Roig and Clavé, 2014). Most studies gather very small samples of blogs and reviews usually not exceeding a few dozen entries. For example, Choi et al. (2007) studied 14 travel blogs, Carson (2008) 25, Bosangit et al. (2009) 30, Pan et al. (2007) 40, Wenger (2008) 188, Chen et al. (2008) 232, Koerte (2009) 364 blogs. As it was observed that travel blogs may be located as individual or be located within specialized websites hosting travel blogs. Individual blogs usually consist of several entries (separate posts of information) posted by the same author/s. Within travel blog hosting websites, the disposition of information is similar (by entries as separate posts of information) but posts do not belong to the same author, but to multiple authors. The information in these blogs is not ordered by author but by other criteria (entries are mainly classified by date and geographical region or destination (Carson, 2008).

In this study, both individual blogs and specialized websites hosting travel blogs were included in the data base to study. For the individual blogs, we started with a research Google using the keywords travel blogs on Egypt. An essential reason for choosing Google as the search engine is that Google's PageRank algorithm ranks documents based on popularity, Google is generally identified as the most popular and reliable search engine through the world (eBizMBA,2016). As a result, two top travel blog sites travelblog.org and travelpod.com were selected in terms of the rank of Google. These sites have a hierarchical directory of blogs (continents, countries, provinces and cities). For both individual and specialized travel blogs, we retained only the entries written by writers who choose to give information about themselves. For individual blogs, we also excluded the ones written with a commercial connotation. For Specialized blogs, we detected blog entries written by the same person and their travel experiences were on the last five years starting from June 2011 to June 2016. This step leads to the reduction of the number of blog entries to analyses. For individual blogs, only 22 blogs met the criteria from 33. The specialized travel blogs the final number of blogs entries is: 97 on Travelblog.org, 46 on Travelpod.com. All the blogs articles are written in English language. All of them contained pictures taken during the trips to Egypt. The blog articles collected for the research describe travel stories, which included some personal details. The bloggers also described to readers how the trip was arranged, the choice of transport, hotel prices as well as a lot of practical details. Most stories concentrated on the travel destination describing its nature, climate, historical details and so on. Blog texts were followed by response comments. By commenting, blog readers ask questions, evaluate the presented information, share their own travel experience and express their travel decision making regarding Egypt as a destination.

\section{Data analysis}

A content analysis codebook was developed to categorize several elements in the visitors' blogs, specifically the elements that were engaged with destination choice of the tourists. There are so many factors affecting choice process of a tourist. These factors that are related to the destination: e.g. distance, type of area, infrastructure, size of area, type of vegetation and activities in the destination (Hsu et al, 2009). Nicolau and Mas (2006) summarized 17 factors affecting destination choice of the tourist. These factors were surface area, price, natural attributes, infrastructure, accessibility, programmed activities, reputation of the destination, restrictions of navigation, population of species, 
time of journey, entry prices, hotel size and services, parking areas and shops. After detailing the 165 blogs, a coding and classification system was adopted to analyze the content efficiently and clearly. As can be seen in Table 1, six main attributes and 24 sub-attributes were driven by the data. These attributes are consistent with the attributes that are found in previous studies (Buhalis, 2000; Omerzel, 2006; Nicolau and Mas 2004; Hsu et al, 2009) and give complementary information to the previously described results of the content analysis in this study. The attributes were labeled destination facilities and service quality, accessibility, People and safety, price, attractiveness and Tourist activities. Each attribute included sub- attributes that were used to obtain more detailed analysis and findings. The number of positive and negative comments was the basis of the content analysis.

Table 1 - Attributes and sub- attributes of Egypt's choice as a tourist destination

\begin{tabular}{|l|l|}
\hline \multicolumn{1}{|c|}{ Attributes } & \multicolumn{1}{c|}{ Sub-attributes } \\
\hline Destination Facilities and & Accommodation \\
service quality & Market and shopping area \\
& Overpricing \\
& vendors attitude \\
& Local infrastructure \\
& Streets (crosswalks, noisy, lights and cleanliness) \\
& Tourist guidance \\
& Food service facilities \\
\hline Accessibility & Airport efficiency \\
& Local tourism transportation efficiency \\
& Cab drivers \\
\hline People and Safety & Friendly people \\
& People's harassment or cheat \\
& Personal safety \\
& Less crime \\
\hline Price & Hotel prices \\
& food prices \\
& Crafts' as the souvenirs' prices \\
& Transportation fair \\
\hline Attractiveness & Weather \\
& Historical, Natural and cultural attractions \\
\hline Tourist activities & Night life \\
& Nature based activities \\
& Cultural based activities \\
\hline
\end{tabular}

\section{Results and discussion}

\section{Bloggers profile}

Bloggers' personal information was traced from their profiles. In spite of the fact that bloggers are talking about their personal travel experiences, they prefer not to provide open access to personal information. Demographic data, such as age, place of living, employment and family status were available only in few travel blogs. The only available demographic data in all the cases was gender 
and bloggers' countries. It was estimated that $43 \%$ of blogs were written by men, $51 \%$ by female authors, and $6 \%$ of blog articles were written by couples (co-production). $20 \%$ of bloggers are from USA, 10\% are from Australia, 10\% are from Canada, 50\% are from Europe, 5\% from Africa and 5\% from Latin America. The average length of stay in Egypt was 7 days and all bloggers classified their visits across Egypt in a chronological order. As can be seen in Table 2 the top visited destinations were in Upper Egypt that extends from Aswan to Giza.

Table 2- List of number of visits by bloggers to tourist Egyptian destinations

\begin{tabular}{|l|l|}
\hline \multicolumn{1}{|c|}{$\begin{array}{c}\text { Egyptian tourism } \\
\text { destinations }\end{array}$} & $\begin{array}{c}\text { Number of visits by } \\
\text { bloggers }\end{array}$ \\
\hline Cairo & 78 \\
\hline Luxor & 53 \\
\hline Aswan and Abu Simble & 44 \\
\hline Giza & 38 \\
\hline Sharm ElSheikh & 29 \\
\hline Hurghada & 19 \\
\hline Alexandria & 17 \\
\hline Western desert Baheria & 7 \\
\hline Siwa & 4 \\
\hline Suez Canal & 6 \\
\hline Port Said & 5 \\
\hline Fayoum & 1 \\
\hline
\end{tabular}

Table 3- Coding Attributes and Number of Positive and Negative Comments

\begin{tabular}{|c|c|c|c|c|}
\hline Coding Attributes & Positives & Negatives & $\begin{array}{c}\text { Total } \\
\text { Sentences }\end{array}$ & $\begin{array}{c}\% \text { of } \\
\text { Negative } \\
\text { Sentence }\end{array}$ \\
\hline \multicolumn{5}{|l|}{ Destination Facilities and service quality } \\
\hline Accommodation & 97 & 39 & 136 & $28.7 \%$ \\
\hline Market and shopping area & 15 & 9 & 24 & $37.5 \%$ \\
\hline Overpricing & 7 & 33 & 40 & $82.5 \%$ \\
\hline vendors attitude & 6 & 28 & 34 & $82.4 \%$ \\
\hline Local infrastructure and traffic & 16 & 46 & 62 & $74 \%$ \\
\hline $\begin{array}{l}\text { Roads (crosswalks, noisy, lights and } \\
\text { cleanliness) }\end{array}$ & 10 & 50 & 60 & $83.3 \%$ \\
\hline Tourist guidance & 17 & - & 17 & $0 \%$ \\
\hline Local food quality and service & 138 & 19 & 157 & $12 \%$ \\
\hline \multicolumn{5}{|l|}{ Accessibility } \\
\hline Airport efficiency & 3 & 19 & 21 & $90.4 \%$ \\
\hline Local tourism transportation efficiency & 34 & 34 & 68 & $50 \%$ \\
\hline Cab drivers & 15 & 21 & 36 & $58.3 \%$ \\
\hline \multicolumn{5}{|l|}{ People and Safety } \\
\hline Friendly people & 48 & 28 & 76 & $36.8 \%$ \\
\hline
\end{tabular}




\begin{tabular}{|l|c|c|c|c|}
\hline People's harassment or cheat & 4 & 47 & 51 & $92.1 \%$ \\
\hline Personal safety & 30 & 18 & 48 & $37.5 \%$ \\
\hline Less crime & 6 & 4 & 10 & $40 \%$ \\
\hline Price & 28 & 4 & 32 & $12.5 \%$ \\
\hline Hotel prices & 22 & 5 & 27 & $18.5 \%$ \\
\hline food prices & 16 & 8 & 24 & $33.3 \%$ \\
\hline Crafts' as the souvenirs' prices & 14 & 6 & 20 & $30 \%$ \\
\hline Local transportation fair & 18 & 18 & 36 & $50 \%$ \\
\hline Attractiveness & 209 & 31 & 240 & $12.9 \%$ \\
\hline Weather & \multicolumn{5}{|l}{} \\
\hline $\begin{array}{l}\text { Historical, Natural and cultural } \\
\text { attractions }\end{array}$ & \multicolumn{5}{|l|}{} \\
\hline Tourist activities & 9 & 2 & 11 & $18.2 \%$ \\
\hline Night life & 34 & 1 & 35 & $2.9 \%$ \\
\hline Nature based activities & 4 & 3 & 7 & $42.9 \%$ \\
\hline \begin{tabular}{l} 
Cultural based activities \\
\hline
\end{tabular}
\end{tabular}

Content analysis identified the highest and the lowest attributes that summarize the data about travel experiences in Egypt as posted in travel blogs. The identified attributes embrace the most important travel aspects discussed in those blogs. Each attribute had several sub-attributes that were used to obtain more detailed analysis and findings. For all the attributes, the sum of positive and negative comments was calculated and percentage of negative comments was extracted. As Table 3 shows the most and the least negative comments on the identified attributes. Bloggers were discontent with people's harassment or cheat which received the most negative comments $(92.1 \%)$ and were content with nature based activities which received the least negative comments (2.9\%), while Tourist guidance achieved $(0 \%)$ negative comments.

For destination Facilities and service quality attribute, this attribute embraces all the aspects discussed in the blog texts related to the Egypt facilities' and its service quality by bloggers during their trips. In this attribute, local food quality and service achieved the least negative comments with (12\%). One of the bloggers talked about local food "As for local cuisine... Egyptian food is the nicest I've ever tasted", another blogger said "Though falafel is enjoyed all over the Middle East, Egypt is recognized as the first to eat these flavorful deep fried treats" another says "I couldn't get over the quality and affordability of dates in Egypt. I bought a few kilos straight from Siwa Oasis". Accommodation achieved the second least negative comments with (28.7\%), some excerpts explain this: "My accommodation offers was an extremely welcome site" or" The hotel is very nice ;^) and the rooms are very clean" or "In my opinion this room is filled to the rafters with luxurious furniture, up to date technology and picturesque views of the bordering Nile river" and at last "The Nile cruise was fabulous and the food was to die for". 


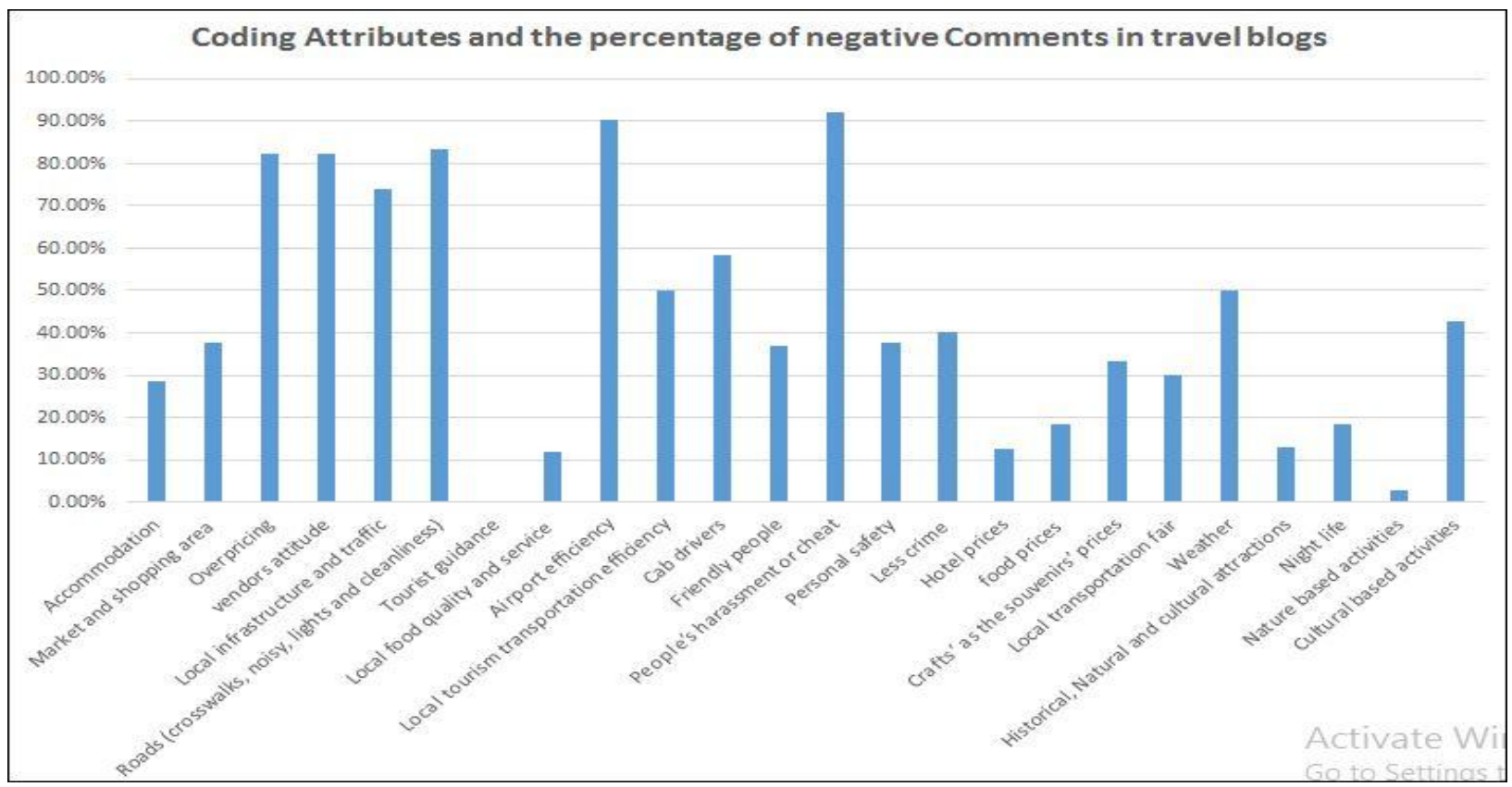

Figure 4: Coding Attributes and the percentage of Negative Comments in travel blogs

Roads (crosswalks, noisy, lights and cleanliness) received the most negative comments (83.3\%) as a sub-attribute to destination facilities and service quality attribute. The following examples illustrate one of these observations: "To the Catacombs of Kom ash-Shuqqafa. The bus driver skillfully navigated narrow dirt streets jammed with donkey carts" another observation" cars swerve around recklessly and honk at each other as if they just discovered what a "horn" was "or "listening to the to Cairo streets and ever present honking of horns in a jumbled melody" and "One of the best and most effective methods of crossing a street is to look the driver directly in the eye and then extend your arm out and point your index finger directly into his/her face as if holding them back". Both overpricing and vendors attitude achieved the second most negative comments with ratio up to (82.5\%) and (82.4\%). Bloggers mentioned that for overpricing, "You have to start your bargain price much below the 1/3 price and most of the time you would end up with a good bargain" another comment "Typical market shops (90\% of shops) when you ask how much they start with high price. The tactic is to look at them like your saying 'your joking right? Say 'too much, too much' and slowly start walking off. The price will then suddenly" and at last "The restaurant tries to overcharge us when we ask for separate checks, sneaking duplicate charges on everyone's bill thinking we wouldn't notice!'”. Bloggers said for vendor's attitude "Our guide said to not take anything from anyone who was offering items as gifts" also said "The vendors are merciless" and "shopkeepers are quite aggressive". Local infrastructure and traffic received (74\%) of the negative comments, some of these comments were, "In the temple, I check out the bathrooms, when I realized that I didn't even want to go in the first place" or "The roads were in poor condition, consisting of old asphalt with no lane markings" or" In the tourist Information office, the employees there were conflicting and clearly bogus" and "When they say no traffic rules in Cairo, they mean really no traffic rules". Market and shopping area received just (37.5\%) of the negative comments, as bloggers said "The market experience was chaotic, begging children thrust there hands into the crowd demanding money as larger young men pushed them away" and "The stall owners hover out the front of their shops their keen eyes stalking those of tourists who if so much as glance in the direction of any of their wares are 
quick to jump out and initiate small talk". But from their positive comments, "You can purchase personalized cartouche necklaces or bracelets, with their name spelled in hieroglyphics" and "In Khan El Khalili bazaar displays of gold and silver shops, pashminas and kaftan display and tacky souvenir stores aplenty, perfumes shops accompanied by the smells of sheesha's from the ahwa's and spices". Tourist guidance has achieved $(0 \%)$ negative comments, content analysis found no complain from any blogger. On the contrary all bloggers give positive comments for Egyptian tourist guides such as, "our guide has been wonderful and is so passionate about her country and the history" or "our wonderful guide has taken such great care of us" and "The beauty of this trip for me is having my Egyptian guide”.

For accessibility attribute which embraces airport efficiency as a sub-attribute achieved the highest negative comments (90.4\%). As bloggers described in their comments, "The airport was so confusing when we arrived, no one spoke English; no one told us that we were at the Domestic Flights building and needed to go to the International Building" or "When I arrived at the terminal, the bus signs were written in Arabic" or "Passport control was dodgy as well. The guy who stamped our passports kept them, and told us to keep going! He said we would get it when we flew out! "or "This misadventure of wonders started when I arrived to El Cairo airport and decided to go to the toilet, small man at the toilet actually wanted me to pay him for handing me over toilet paper" and "Arriving in the Cairo airport, things did not start out ideally". Cab drivers achieved (58.3\%) of the negative comments, bloggers' excerpts explained better their attitude. "Taxi drivers were following us telling us to ride with them" or "The taxi driver was quick, the ride was too crazy" and "a taxi driver pounced upon me, trying with effort to hustle me into taking his taxi". Local tourism transportation efficiency achieved the lowest negative comments as a sub-attribute (50\%), Bloggers mentioned that "the bus area was a bit confusing, as the buses are not marked very well and we noticed that nobody really knew English where we were" and "Getting on the Cairo metro at peak hours of traffic is like being in a rugby scrum". As a positive comment, "We got comfortable with our first class train tickets which were well worth it".

For People and Safety attribute, people's harassment or cheat achieved the highest negative comments in all attributes (92.1\%). bloggers talked about that, "You can't avoid the hassle in here" or "As a female: I ventured out alone for lunch today, the worst comments I got were" another female blogger said "Young men running up to me in the Qaitbay Citadel continually asking for my photo". A male blogger stressed that "there is a great amount of hassle to tourists in Egypt" and another said, "We were tricked by grifters and hassled for baksheesh". Less crime achieved (40\%) of the negative comments, One of the bloggers said, "I got pickpocketed last night, on my second night here", another bloggers advice was, "Take care of your passport and valuables. Use hotel safes and beware of pickpockets and bag snatchers" another said "I was a victim of robbery". Personal safety achieved (37.5\%) some bloggers said, "I felt safe but, of course, you had the Russian plane from Sharm that blew up a few months later over the Sinai" another said "in addition, to the terrorists you have the old-school hijackers like the Egyptian man who recently diverted an internal Egyptian flight to Cyprus to see his ex-wife" But at the sometime another bloggers see that, "The country is quite safe" and "I'm happy and feeling safe". Friendly people as a sub-attribute achieved (36.8\%), One blogger wrote that," all Egyptians are liars and they do not tell you one good info" but another said "here there were good people and there were bad people". Bloggers explained positively that, "The Egyptian people are so friendly", "Egyptians treat guests well and take hospitality seriously" and 
"Individuals enact their Egyptian hospitality, often willing to go the extra mile to ensure a foreign visitors safety and satisfaction in Egypt".

For Price attribute, Bloggers indicated that one of the reasons to visit Egypt was its prices. Bloggers do not use luxury resorts or fancy restaurants; they just want a good meal and a quiet night sleep. As they expressed, "One reason we visited Egypt was due to the low cost of traveling at the current time" or "the Egyptian Pound (LE or EGP) is at a very favorable exchange rate at the moment". For Hotel prices, as a sub-attribute achieved (12.5\%). They pointed out that, "Accommodation throughout the country can be fantastic value. Even in the capital Cairo, a budget hostel can be just a few GBP a night", "whilst a spacious private room with en suite in a pension can be yours for just £20 to £25 GBP", another female blogger said, "Giza after exchanging my Canadian money into the Egyptian pound. I had booked the Pyramids View Inn for the astounding price of only $\$ 45$ CAD per night which totaled up only $\$ 225$ CAD for my 5 night stay in Egypt”. For food prices, as a sub-attribute achieved (18.5\%), as one blogger described local food, "Food is extremely cheap, especially if you stick to street stalls and local eateries" another one said, "Outside of the market is a small falafel stand where you can buy cheap sandwiches for 2 LE each". One of their negative comments on fast food was "The western fast food chains and restaurants can be pricey however so you can save a lot of money by avoiding these places". For crafts' as the souvenirs' prices achieved (33.3\%) as they described negatively, "There is an overabundance of tourist shopping in Egypt. Usually souvenirs at sites of interest are overpriced, though with a fair amount of chitchat, there are deals to be made" or "don't buy spices in a tourist market when the locals buy them for much cheaper outside in nontourist markets" and they also added that "there are many characters in the market. One man yelled "buy one get one freeeee!!!!" as we were leaving. Others will say "everyone inside 1 pound." This is clearly not true, and I try to stay away from places that make such claims. In fact, I found myself often going into the stores where we were not pulled into". But they confirmed that, "The Aswan market souk is a great place to buy things to take home from Egypt" and "For souvenirs and bed linen I would definitely go to the famous Khan el Khalili market". For Local transportation fair, it achieved (30\%), they stressed that, "if you need to take a taxi, locate a white taxi, it is quite affordable, avoid the black taxis as you will probably be overcharged"," just take Uber, it is the right choice" they also added, "public transport is significantly less. Egypt's rail network is not good enough but you can get to most places within Egypt for very little". They confirmed positively that, "air conditioned buses are reasonable value, especially given the distances involved" and "You can always talk to a train attendant to see if he has open seats somewhere, if he directs you to a better seat, a little tip (baksheesh) is necessary".

For Attractiveness attribute, Weather as a sub-attribute achieved (50\%) negative comments, some of them mentioned that, "the weather is wonderful. It is dry and sunny every day so a perfect time to be here", "the weather is just fantastic and we can see why the Europeans come here a 4-5 hour flight and good diving. It is like Mexico or Hawaii for us" or "I forgot to mention how nice the climate is here". But on the other hand, some bloggers mentioned that, "the Egyptian summer and the temperatures can often be very high, especially in Upper Egypt", "avoid the Khamsin wind season that runs between March and April" and "the fair-skinned, wearing a sunhat is essential". For historical, natural and cultural attractions sub-attribute achieved (12.9\%) negative comments, bloggers described, "The Pyramids, and the Sphinx! Wow! just wow!", "Dahab is a haven for scuba, snorkeling, wind surfing and kite surfing" and "I love Cairo because it's impossible to get bored when you're there", "Ras Muhammed in Sharm El-Sheikh is Egypt's most famous national park and 
diving spot, and among the most known diving sites in the world" and "the Blue Hole was crazy experience". They described negatively, "Despite a rather negative experience at the pyramids, my experience in Egypt overall was a positive one" or "the Pyramids and Sphinx were amazing and well worth all the hassle we had endured to get to this point" and "most tourists in Egypt visit only Cairo and Luxor. Few visit Alexandria, the country's second city, and one of the great cities of the Mediterranean".

For tourist activities attribute, Night life as a sub-attribute achieved (18.2\%) negative comments, as they described, "Last night was good fun as we dressed in traditional Egyptian dress and had a fabulous dinner with some traditional foods", or "A trip to Cairo isn't complete without seeing a show featuring Cairo's famous Sufi dancers". For nature based activities which achieved (2.9\%) the least negative comments at all. Bloggers described that, "Snorkeling was very good but diving was the best" or" Lake Qaroun where water sports and fishing can be practiced, as well as Bird Watching" and "Wadi Lahami lagoon is located at a remote area near to Marsa Allam which makes it off-the-beaten track compared to its peers in Dahab \& Sharm El-Sheikh. It's truly a water sports escape". For cultural based activities which achieved (42.9\%), the positive comments were, "The Luxor Museum, made possible and designed by the people who brought us the Louvre in Paris, is the finest museum in the country" and "Alexandria's top attraction is its futuristic modern library, the library is a delight of modern architecture". While the negative comments were, "within the Cairo Garbage City you will find a cave church named the Monastery of St. Simon" or "I wish we would have been able to see the burning bush and the inside of the old monastery St. Catherine's, but we did not get to".

\section{Strengths and Weaknesses of Egypt's attributes}

The content analysis identified that the most attributes that made tourists' choice to select Egypt as a tourist destination were the historical attractions especially pyramids, Luxor and Aswan. The natural attributes especially Sharm Elsheik and Dhab and the water activities accompanied. The convenient price and the observed lifestyle of local people also discussed and drew their attention to Egypt. Although people' hassle (from blogger's point of view) was the main reason that make many tourists avoid visiting Egypt beside their concerns about safety. The results revealed that the major strengths of the destination of Egypt lie in its nature activities, its historic attractions, the beaches and water activities. The local food quality and service, its prices and hotel prices are considered the main reason for Egypt's choice as a tourist destination. Tourist guidance is also considered one of its strengths from bloggers point of view. The major weaknesses were people's harassment or cheat, the lack of airport efficiency and poor local infrastructure (roads and traffic). Despite the majority of positive sentences, bloggers expressed many complaints about the infrastructure, especially road conditions and traffic signs. Besides all above, vendor's attitude and overpricing are considered from the overall complaints that stood out.

\section{The study implications for Marketing}

The study results demonstrated that analysis of travel blogs can reveal detailed and in-depth information about the characteristics of a destination, which cannot be gathered from the measurement of visitor surveys. The results presented above will allow Destination management Organizations in Egypt to have a better understanding of the market. Bloggers' information should be used to improve the perceived image so the DMOs would be able to understand this matter as a 
whole. The value of analyzing blogger's generated content can help to increase the tourism information of tourism marketing managers. There is no denying that a rich and varied stream of travel and tourism information is available online these information can be extracted, summarized and re-presented in an intelligible and relevant form to the decision makers who need it.

\section{Recommendations, limitations and future research}

The choice of this study to analyze travel blogs to reveal tourists' interpretations of services, experiences and products to stimulate the responsible for tourism marketing in Egypt to monitor major travel blog sites and assess its member's readiness for using blogs in a strategic way. For DMOs in Egypt, there are a range of recommended applications for tourist generated content found within the travel blogs such as: (1) Identifying and monitoring trends in traveller movements to and from Egypt as a tourism destinations such as previous and future stopover locations. (2) Specific product evaluations and reviews of service standards. (3) Identification of Egyptian tourist products or infrastructure gaps (airports, roads, eg). (4) Performance reviews of associated products (local transportation) or collaborators (such as shopkeepers and vendors). (5) Raise awareness for local people to improve their attitude towards tourists. (6) Competitor analysis to improve tourist products and services quality. (7) Tourism practitioners and marketers should notice that tourists use online services increasingly and that online word-of-mouth is taking a prominent place among other marketing tools. Tourists share their experience, judgments, perceptions and images more easily with other potential visitors online.

This study have a number of limitations, the sample was not enough, not representing all foreign visitors to Egypt and of course not based on different demographic variables such as nationality, age, gender, income and social status. In other words, this study included only visitors who have published their experience on their weblogs. Accordingly, the findings of this study are not generalizable. While the study attempts to understand visitors' online publishing, no interviews were conducted with this group of respondents to detect other possible features, which may influence their destination choice.

Future research needs to explore other frameworks that will be appropriate in maximizing the usefulness of travel blogs to the academics and to the industry. Researchers must be encouraged to identify more possible uses of travel blogs in understanding the rapid and continuously changing tourist consumption. Identifying of tourists and sense-making represents only one aspect of the blogging activity among tourists. To explore this blogging activity of tourists, it is suggested that researchers follow how blogs in general have been examined. To date, the blogging phenomenon has rich literature examining multiple functions of blogging such as social networking, knowledge/information sharing, life-documenting, communication and identity construction. An indepth examination of this phenomenon may identify new trends in tourist consumption that may have marketing and management implications.

\section{References:}

- Albarq, A. N., (2014), "Measuring the Impacts of Online Word-of-Mouth on Tourists' Attitude and Intentions to Visit Jordan: An Empirical Study", International Business Research, Vol. 7 (1), 14-22.

- Arat, T., (2016), "A study on travel blogs and word of mouth communication", The proceedings of the 21st International Academic Conference, Miami, Online issue.

- Banyai, M., (2010), "Dracula's Image in Tourism: Western Bloggers versus Tour Guides." European Journal of Tourism Research, 3 (1): 5-22. 
- Banyai, M. and Glover, T.D., (2012), "Evaluating Research Methods on Travel Blogs", Journal of Travel Research, 51(3), 267-277.

- Berger, I.E. and Greenspan, I., (2008), "High (on) technology: Producing tourist identities through technologized adventure", Journal of Sport \& Tourism, 13(2), 89-114.

- Bickart, B. and Schindler, R.M., (2001), "Internet forums as influential sources of consumer information", Journal of Interactive Marketing, 15(3), 31-40.

- Bonner, F., and De Hoog, R. (2011), "Vacationers and e-WOM: Who posts, and why, where, and what?", Journal of Travel Research, Vol50 pp.15-26.

- Bosangit, C., McCabe, S., and Hibbert, S., (2009), "What is Told in Travel Blogs? Exploring Travel Blogs for Consumer Narrative Analysis”, In W. Hopken, U. Gretzel, \& R. Law (Eds.), Information and Communication Technologies in Tourism 2009 (pp. 61-71), The Netherlands: SpringerWienNewYork.

- Buhalis, D., and Law, R., (2008), "Progress in information technology and tourism management: 20 years on and 10 years after the internet: The state of e-Tourism research", Tourism management, 29, 609-623.

- Buhalis, D., (2000), "Marketing the Competitive Destination of Future", Tourism Management, (21): 97-116.

- Carson, D., (2008), "The 'blogosphere' as a market research tool for tourism destinations: A case study of Australia's Northern Territory", Journal of Vacation Marketing, vol.14, no.111, pp.115-140.

- Chen, H.J., Yung, C.Y. and Wang, M.H, (2008), "Perception gaps between tourist blogs and travel information on destination image", 26th EuroCHRIE Conference, Oct. 12-14, 2008 Dubai.

- Cheung, C. M. K. and Lee M. K. O., (2012),"'What drives consumers to spread electronic word of mouth in online consumer-opinion platforms", Decision Support Systems, vol. 53, no. 1, pp. 218-225.

- Choi, SJ., Lehto, XY., and Morrison, AM. (2007), "Destination image representation on the web: content analysis of Macao travel related websites", Tourism Management, 28(1):118-129.

- Dalen,S.V.,(2014), “An online journey to find the perfect holiday destination: How does the exposure to travel blogs influence decisions about potential holiday destinations of travellers?" A thesis submitted to Communication and Information sciences department, Tilburg University, Netherlands.

- Dellarocas, C., (2003), "The Digitization of Word of Mouth: Promise and Challenges of Online Feedback Mechanisms." Management Science, 49(10): 1407-1424.

- Ellion, (2007), "Web 2.0 and the travel industry: practical strategies for exploiting the social media revolution". White paper.

- Gelb,BD. and Sundaram, S., (2002), “Adapting to word of mouse”, Business Horizons, 45(4): 21-25.

- Goldsmith E R., Litvina W.S., Pana B., (2008), "Electronic word-of-mouth in hospitality and tourism management", Tourism management, Vol 29 pp 458-468.

- Gu, B., Law, R., and Ye, Q. (2009), "The impact of online user reviews on hotel room sales", International Journal of Hospitality Management, Vol,28 Iss. 1 pp. 180-182.

- Hansen, S. S. and Lee, J. K., (2013), "What drives consumers to pass along marketer-generated e-WOM in social network games? social and game factors in play", Journal of Theoretical and Applied Electronic Commerce Research, vol. 8, no. 1, pp. 53-68.

- Hennig-Thurau, T., Gwinner, K. P., Walsh G. and Gremler, D. D., (2004), "Electronic word-of-mouth via consumer-opinion platforms: What motivates consumers to articulate themselves on the internet", Journal of Interactive Marketing, vol. 18, no. 1, pp. 38-52.

- Hsu, H.Y., Tsai, H.T. and Wu, H., (2009), "The preference analysis for tourist choice of destination: a case study of Taiwan", Tourism Management, 30: 288-297.

- Hsu H.Y. and Tsou H.T., (2011), "Understanding Customer Experiences in Online Blog", Environments, International Journal of Information Management, Volume 31, Issue 6.

- Hsu, C-L., Chuan-Chuan Lin, J. and Chiang, H-S., (2013), "The effects of blogger recommendations on customers' online shopping intentions", Internet Research, 23(1), 69-88.

- Jalilvand, M. R., Esfahani, S. S. and Samiei, N., (2011), "Electronic word-of mouth: Challenges and opportunities", Procedia Computer Science, vol. 3, pp. 42-46.

- Kelleher, T. and Miller, BM., (2006), "Organizational blogs and the human voice: relational strategies and relational outcomes" Journal of Computer-Mediated Communication,11(2).

- Koerte, T.R., (2009), "The projected and perceived image of the United Republic of Tanzania", CFS Honors Program Undergraduate Theses, Paper 8. Retrieved from http://docs.lib.purdue.edu/cfstheses/8

- Lee, M. and Youn, S., (2009), "Electronic word of mouth (e-WOM): how e-WOM platforms influence consumer product judgment", International Journal of Advertising, 28(3), 473-99. 
- Lepp, A. and Gibsonb, H., (2008), "Sensation seeking and tourism: Tourist role, perception of risk and destination choice", Tourism Management, 29(4), 740-750.

- Li,W.,(2015), "Exploring tourists' attitudes towards Macao: a semantic network analysis of micro-blogs", Sustainable Development, Vol. 2807.

- Litvin, S., Goldsmith, RE. and Pan. B., (2007), "Electronic word-of-mouth in hospitality and tourism management", Tourism Management. http://www.ota.cofc.edu/pan/. Retrieved 17 April 2008.

- López, M. and Sicilia, M., (2014), "Determinants of E-WOM Influence: The Role of Consumers' Internet Experience", Journal of Theoretical and Applied Electronic Commerce Research, Electronic Version, vol 9 / issue 1 / January.

- Mariné-Roig, E. and Clavé, S.A., (2014), "Methodological Approach to a Massive Destination Content Analysis of Travel Blogs and Reviews" a conference paper on the7th World Conference for Graduate Research in Tourism, Hospitality and Leisure: 178-184, 03 - 07 June 2014, Istanbul, Turkey

- Mills and Law, (2004) in Basarani, S., (2011), "Electronic Word of Mouth - Managing online guest reviews in the hospitality industry", A Master's Dissertation submitted to Södertörn university, Department of Business studies.

- Monga, N., Pandey, D., and Bhalla, K., (2015), "Managing e-commerce industry in India”, International Journal of Advanced Research in Management and Social Sciences, Vol. 4- No. 4 -April.

- Nicolau, J. L. and Más, F. J., (2006), "The influence of distance and prices on the choice of tourist destinations: The moderating role of motivations" Tourism Management, 27(5), 982-996.

- Omerzel, G, D, (2006), “Competitiveness of Slovenia as a Tourist Destination”, Managing Global Transitions, 4 (2): 167-189.

- Pan, B., MacLaurin, T. and Crotts, J.C., (2007), "Travel Blogs and the Implications for Destination Marketing", Journal of Travel Research, vol.46, no.35, pp.35-45.

- Price, J. and Starkov, M., (2006), "Building a blog strategy in hospitality: grow customer relationships and direct online revenue", Retrieved from Hospitality Net Web Site: http://www.hospitalitynet.org/news/4026867.html.

- Pudliner, B.A., (2007), "Alternative literature and tourist experience: Travel and tourists weblogs", Journal of Tourism and Cultural Change, 5(1), 46-59.

- Pühringer, S. and Taylor, A., (2008), “A practitioner's report on blogs as a potential source of destination marketing intelligence", Journal of Travel Research, vol.14, no.2, pp.177-187.

- Schmallegger D. and Carson D. (2008). Blogs in Tourism: Changing Approaches to Information Exchange, Journal of Vacation Marketing, vol. 14 no. 2 99-110.

- Sharda, N. and Ponnada, M., (2008), "Tourism blog visualizer for better tour planning", Journal of Vacation Marketing, 14(2): 157-167.

- Silverman, G., (2001), in Basarani, S., (2011), "Electronic Word of Mouth - Managing online guest reviews in the hospitality industry", A Master's Dissertation submitted to Södertörn university, Department of Business studies.

- The e-Business Guide, eBizMBA, Top 15 Most Popular Search Engines, July 2016, http://www.ebizmba.com/articles/search-engines

- Tussyadiah, I.P. and Fesenmaier, D.R., (2008), "Marketing places through first-person stories - An analysis of Pennsylvania Roadtripper guide, Journal of Travel \& Tourism Marketing, 25(3), 299-311.

- Volo, S., (2010), "Bloggers' reported tourist experiences: Their utility as a tourism data source and their effect on prospective tourists", Journal of Vacation Marketing, 16(4) 297-311.

- Wang, H-Y., (2012), "Investigating the determinants of travel blogs influencing readers' intention to travel" The Service Industries Journal, 32(2), 231-255.

- Wang, Y., and Fesenmaier, DR., (2006), "Identifying the success factors of web-based marketing strategy: an investigation of convention and visitors bureaus in the United States", Journal of Travel Research, 44(3):239249.

- Waldhor, K., (2007), "etBlog Analysis - analyzing touristic webblogs and forums using statistical and computer linguistic methods for quality control', presented at the 'blogs in tourism' conference, Kitzbuhel, 12 July, Krems Research Forschungsgesellschaft mbH.

- Wenger, A., (2008), "Analysis of travel bloggers' characteristics and their communication about Austria as a tourism destination", Journal of Vacation Marketing, vol.14, no.2, pp.169-176.

- www.statista.com/statistics/256235/total-cumulative-number-of-tumblr-blogs 
